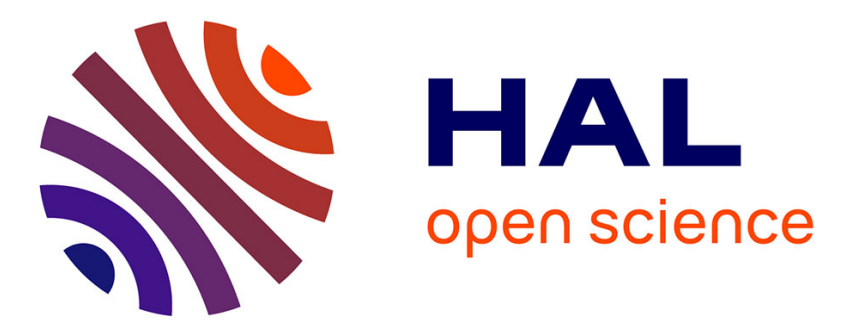

\title{
Double amorphous silicon-carbide p-layer structures producing highly stabilized pin -type protocrystalline silicon multilayer solar cells
}

\author{
Seung Yeop Myong, Koeng Su Lim, Joshua Pearce
}

\section{To cite this version:}

Seung Yeop Myong, Koeng Su Lim, Joshua Pearce. Double amorphous silicon-carbide p-layer structures producing highly stabilized pin -type protocrystalline silicon multilayer solar cells. Applied Physics Letters, 2005, 87 (19), pp.193509. 10.1063/1.2126802 . hal-02119520

\author{
HAL Id: hal-02119520 \\ https://hal.science/hal-02119520
}

Submitted on 3 May 2019

HAL is a multi-disciplinary open access archive for the deposit and dissemination of scientific research documents, whether they are published or not. The documents may come from teaching and research institutions in France or abroad, or from public or private research centers.
L'archive ouverte pluridisciplinaire HAL, est destinée au dépôt et à la diffusion de documents scientifiques de niveau recherche, publiés ou non, émanant des établissements d'enseignement et de recherche français ou étrangers, des laboratoires publics ou privés. 


\title{
Double amorphous silicon-carbide $p$-layer structures producing highly stabilized pin-type protocrystalline silicon multilayer solar cells
}

\author{
Seung Yeop Myong and Koeng Su Lim \\ Department of Electrical Engineering \& Computer Science, KAIST, 373-1 Guseong-dong, Yuseong-gu, \\ Daejeon 305-701, Republic of Korea \\ Joshua M. Pearce \\ Physics Department, Clarion University of Pennsylvania, Clarion, Pennsylvania 16214
}

(Received 31 January 2005; accepted 13 September 2005; published online 3 November 2005)

\begin{abstract}
We have applied double $p$-type amorphous silicon-carbide $(p-a-\mathrm{SiC}: \mathrm{H})$ layer structures to pin-type protocrystalline silicon $(p c-\mathrm{Si}: \mathrm{H})$ multilayer solar cells. The less-pronounced initial short-wavelength quantum efficiency variation against the biased voltage and the wide overlap of dark current-voltage $\left(J_{D^{-}} V\right)$ and short-circuit current-open-circuit voltage $\left(J_{\mathrm{sc}}-V_{\mathrm{oc}}\right)$ characteristics prove that the double $p-a-\mathrm{SiC}: \mathrm{H}$ layer structure successfully reduces recombination at the $p / i$ interface. Therefore, we achieved highly stabilized efficiency of $9.0 \%$ without any backreflector. (0) 2005 American Institute of Physics. [DOI: 10.1063/1.2126802]
\end{abstract}

In recent years, the hydrogen dilution has been a useful deposition technique to change the phase of Si-based thin films. With an increase in the hydrogen dilution ratio $\left(\mathrm{H}_{2} / \mathrm{SiH}_{4}\right)$, we can monitor the phase transition from an amorphous silicon $(a-\mathrm{Si}: \mathrm{H})$-based film to a microcrystalline silicon $(\mu c-\mathrm{Si}: \mathrm{H})$-based film. The latter film contains columnar growth of crystalline silicon $(c-\mathrm{Si})$ grains in an $a-\mathrm{Si}: \mathrm{H}$ matrix. We proposed a double hydrogenated boron-doped amorphous silicon-carbide $(p-a-\mathrm{SiC}: \mathrm{H})$ layer structure consisting of a conventional undiluted $p-a-\mathrm{SiC}: \mathrm{H}$ window layer and $\mathrm{a}_{2}$-diluted $p$ - $a$-SiC: $\mathrm{H}$ buffer layer in order to effectively improve $p / i$ interfaces of amorphous silicon $a$-Si:H solar cells. ${ }^{1}$ The preparation technique of this buffer material is based on that of a highly conductive and wide bandgap hydrogenated boron-doped nanocrystalline silicon-silicon-carbide alloy $(p-n c-\mathrm{Si}-\mathrm{SiC}: \mathrm{H})$ film containing nanocrystalline silicon $(n c-\mathrm{Si})$ grains $(c-\mathrm{Si}$ grains with a size of a few $\mathrm{nm}$ ) embedded in an $a$-SiC:H tissue due to the hydrogen dilution. ${ }^{2-4}$ We reported that the natural hydrogen treatment (etching the defective undiluted $p-a-\mathrm{SiC}: \mathrm{H}$ window layer and increasing dark conductivity of the window layer by improving structural order) occurred just before the highly conductive, low absorption, and wellordered $\mathrm{H}_{2}$-diluted buffer layer deposition onto the window layer. ${ }^{1,5}$ Accordingly, we achieved a high initial conversion efficiency of $11.2 \%$ without any backreflector by successfully reducing the recombination loss at the $p / i$ interface.

On the other hand, we developed alternately $\mathrm{H}_{2}$-diluted protocrystalline silicon $(p c-\mathrm{Si}: \mathrm{H})$ multilayer solar cells. ${ }^{6,7}$ The $p c-\mathrm{Si}: \mathrm{H}$ is an edge material existing just below the threshold of the $a-\mathrm{Si}: \mathrm{H}$ to $\mu c-\mathrm{Si}: \mathrm{H}$ transition. The $p c-\mathrm{Si}: \mathrm{H}$ multilayer cells exhibit the excellent light-induced metastability. Based on the photoluminescent (PL) and Fourier Transform infrared (FTIR) spectroscopy measured at room temperature, we provided strong evidence that regularly arranged isolated $n c-\mathrm{Si}$ grains in $i-p c-\mathrm{Si}: \mathrm{H}$ multilayer absorbers suppress the photocreation of dangling bonds. ${ }^{8}$ In this Letter, we investigated the optimized double $p$ - $a$-SiC:H layer structure for $p c-\mathrm{Si}: \mathrm{H}$ multilayer solar cells and its benefits.

Using the photoassisted chemical vapor deposition
(photo-CVD) system, we fabricated pin-type solar cells at $250{ }^{\circ} \mathrm{C}$ with a simple structure of glass $/ \mathrm{SnO}_{2}: \mathrm{F} /$ undiluted $p$ - $a$-SiC: $\mathrm{H} / \mathrm{H}_{2}$-diluted $p$ - $a$-SiC: $\mathrm{H} / i$ - $p c-\mathrm{Si}: \mathrm{H}$ multilayer $(640 \mathrm{~nm}) / n-\mu c-\mathrm{Si}: \mathrm{H}(40 \mathrm{~nm}) / \mathrm{Al}$ (cell area: $\left.0.092 \mathrm{~cm}^{2}\right)$. To dissociate the gases, we used a low-pressure mercury $(\mathrm{Hg})$ lamp with resonance lines of 184.9 and $273.7 \mathrm{~nm}$ as an uv light source. The undiluted $p-a-\mathrm{SiC}: \mathrm{H}$ films were grown by a direct photo-CVD method using a mixture of $\mathrm{Si}_{2} \mathrm{H}_{6}, \mathrm{~B}_{2} \mathrm{H}_{6}$, and $\mathrm{C}_{2} \mathrm{H}_{4}$ reactant gases. The lightly doped $\left(\mathrm{B}_{2} \mathrm{H}_{6} / \mathrm{SiH}_{4}\right.$ $=1000 \mathrm{ppm}) \mathrm{H}_{2}$-diluted $p$ - $a$-SiC $: \mathrm{H}$ films were prepared by a $\mathrm{Hg}$-sensitized decomposition of a mixture of $\mathrm{SiH}_{4}, \mathrm{H}_{2}, \mathrm{~B}_{2} \mathrm{H}_{6}$, and $\mathrm{C}_{2} \mathrm{H}_{4}$ reactant gases. ${ }^{1}$ The alternately $\mathrm{H}_{2}$-diluted $i$ - $p c$-Si: $\mathrm{H}$ multilayer consists of low $\mathrm{H}_{2}$-diluted $a$-Si: $\mathrm{H}$ sublayers $\left(S_{L}\right.$ 's) and highly $\mathrm{H}_{2}$-diluted $a$-Si:H sublayers $\left(S_{H}\right.$ 's). This repeatedly layered structure is deposited by just modulating the mass flow control of $\mathrm{H}_{2} / \mathrm{SiH}_{4}$ between 0 (for the deposition of $S_{L}$ ) and 20 (for the deposition of $S_{H}$ ) under continuous uv light irradiation. Because we maintained the angle of the throttle valve in the reaction chamber at a constant value during the continuous process, the sublayers deposited under the condition of $\mathrm{H}_{2} / \mathrm{SiH}_{4}=0$ were indeed low $\mathrm{H}_{2}$-diluted $a$-Si: $\mathrm{H}$ layers and all interfaces were graded by hydrogen. In addition, the average deposition rate of the multilayer $(7 \mathrm{~nm} / \mathrm{min})$ is comparable to that of conventional undiluted $i$ - $a$-Si:H $(10 \mathrm{~nm} / \mathrm{min})$. Details were provided in our previous report. ${ }^{7,8}$

In order to obtain the thickness of the undiluted $p$ - $a$-SiC: $\mathrm{H}$ window layer $\left(d_{w}\right)$, thickness of the $\mathrm{H}_{2}$-diluted $p$ - $a$-SiC:H buffer layer $\left(d_{b}\right)$, and the thickness ratio of $S_{H}$ to $S_{L}$ for the $i$ - $p c$-Si:H multilayer $\left(S_{H} / S_{L}\right)$, we performed spectroscopic ellipsometry measurements of angles $(\Psi, \Delta)$ in the range of 1.5-4.0 eV with a phase-modulated spectroscopic ellipsometer (UVISEL-Jobin Yvon). ${ }^{9,10}$ As a result, we achieve a $S_{H} / S_{L}$ value of $32 / 10(\mathrm{~nm} / \mathrm{nm})$. The cell characteristics were measured under $100 \mathrm{~mW} / \mathrm{cm}^{2}$ (AM 1.5) solar simulator irradiation. For spectral response measurements of solar cells, we calculated external quantum efficiencies (QE) in the wavelength region of 400-800 nm via a constant energy monochrometer (light intensity: $50 \mu \mathrm{W} / \mathrm{cm}^{2}$ ). We also measured external QE at a short wavelength of $400 \mathrm{~nm}$ by 


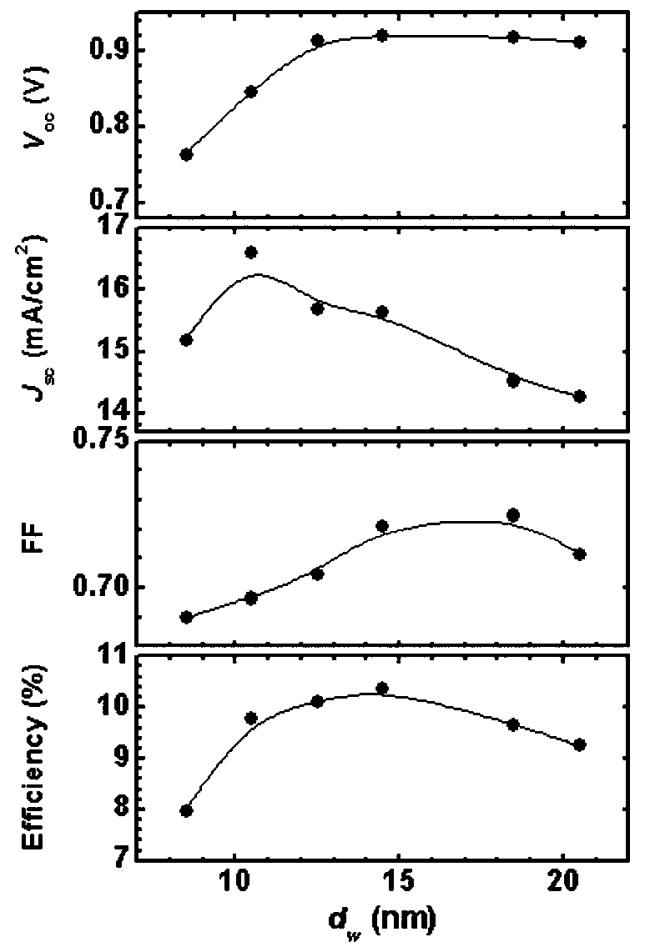

FIG. 1. Initial performance dependence of $p c-\mathrm{Si}: \mathrm{H}$ multilayer solar cells as a function of $d_{w}$. $d_{b}$ is maintained at $2.2 \mathrm{~nm}$.

varying the applied voltage from -1 to $0.4 \mathrm{~V}$ with the step increment of $0.2 \mathrm{~V}$. The dark current-voltage $\left(J_{D^{-}} V\right)$ and short-circuit current-open-circuit voltage $\left(J_{\mathrm{sc}}-V_{\mathrm{oc}}\right)$ characteristics were measured at room temperature. The latter was achieved by varying the illumination intensity in the range of $10^{-7}$ to 1 sun $\left(J_{\mathrm{sc}}=10^{-9}-\sim 10^{-2} \mathrm{~A} / \mathrm{cm}^{2}\right)$.

Figure 1 shows the dependence of solar cell parameters on $d_{w}$. For clarity, $d_{b}$ is maintained at $2.2 \mathrm{~nm}$. The $d_{w}$ value is the final thickness of the window layer after the buffer layer deposition: $\sim 5.5 \mathrm{~nm}$-thick defective surface of the window layer is etched just before the buffer layer deposition. $V_{\mathrm{oc}}$ increases up to $0.920 \mathrm{~V}$ with the increase in $d_{w}$, and then virtually saturated for $d_{w} \geqslant 12.5 \mathrm{~nm}$. $J_{\text {sc }}$ shows its maximum value of $16.6 \mathrm{~mA} / \mathrm{cm}^{2}$ when $d_{w}$ is $10.5 \mathrm{~nm}$. This value is lower than that of the $a-\mathrm{Si}: \mathrm{H}$ solar cell due to lower QE in the long-wavelength region of $600-800 \mathrm{~nm} .{ }^{1,5}$ In the case of a fill factor (FF), it provides the maximum value of 0.725 when $d_{w}$ is $18.5 \mathrm{~nm}$. For $d_{w} \geqslant 18.5 \mathrm{~nm}, \mathrm{FF}$ declines because the electrical loss with the thicker window layer reduces the photogenerated voltage by diminishing the current to the window layer. Therefore, we obtained the maximum initial efficiency by using the $14.5 \mathrm{~nm}$-thick $p-a$-SiC: $\mathrm{H}$ window layer.

Figure 2 displays the spectral response dependence on the variation of $d_{w}$. In the wide wavelength range of $400-640 \mathrm{~nm}, \mathrm{QE}$ increases until $d_{w}$ reaches $10.5 \mathrm{~nm}$. However, QE decreases by a further increase in $d_{w}$.

We found that the dependence of initial cell performance upon the $d_{b}$ value is less sensitive than its dependence on $d_{w}$ like $a$-Si: $\mathrm{H}$ solar cells. ${ }^{1,5}$ Thus, we achieved $\sim 10 \%$ initial efficiency by employing a $1.5-2.5 \mathrm{~nm}$-thick $p-a-\mathrm{SiC}: \mathrm{H}$ buffer layer. For $d_{b}=2.2 \mathrm{~nm}$, we obtained the optimized initial conversion efficiency of $10.4 \% \quad\left(V_{\text {oc }}=0.920 \mathrm{~V}\right.$, $J_{\mathrm{sc}}=15.6 \mathrm{~mA} / \mathrm{cm}^{2}$, and $\mathrm{FF}=0.721$ ). If we do not use the $\mathrm{H}_{2}$-diluted $p$ - $a$-SiC: $\mathrm{H}$ buffer layer, the initial efficiency severely reduces to $7.7 \%$ due to the decrease in all parameters Downloaded 03 Nov 2005 to 130.125.31.205. Redistribution subject

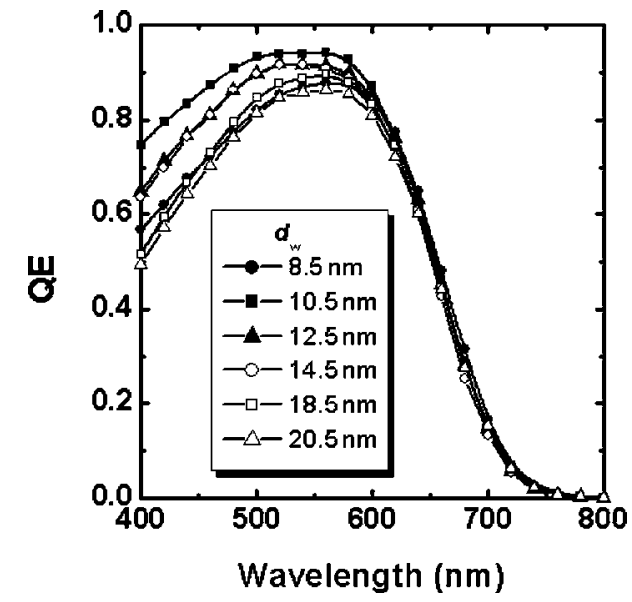

FIG. 2. Initial QE dependence of $p c-\mathrm{Si}: \mathrm{H}$ multilayer solar cells as a function of $d_{w} . d_{b}$ is maintained at $2.2 \mathrm{~nm}$.

$\left(V_{\mathrm{oc}}=0.845 \mathrm{~V}, J_{\mathrm{sc}}=13.6 \mathrm{~mA} / \mathrm{cm}^{2}\right.$, and $\left.\mathrm{FF}=0.670\right)$. The extent of the improvement for the multilayer cell is smaller than that of $a-\mathrm{Si}: \mathrm{H}$ solar cells. ${ }^{1,5}$ Since the first layer of the $i$-pc-Si:H multilayer is ultrathin $(\sim 5 \mathrm{~nm}) S_{H}$, the multilayer cell without the $\mathrm{H}_{2}$-diluted $p-a-\mathrm{SiC}: \mathrm{H}$ buffer also has a weak natural hydrogen treatment during the $p / i$ interface formation. Therefore, the improvement of the multilayer cell by the natural treatment effect during the formation of the double $p-a-\mathrm{SiC}: \mathrm{H}$ layer structure diminishes.

Figure 3 depicts the QE (at a wavelength of $400 \mathrm{~nm}$ ) dependence as a function of the bias voltage. The optimized multilayer cell with the $\mathrm{H}_{2}$-diluted $p$ - $a$-SiC: $\mathrm{H}$ buffer layer exhibits less variation at the short wavelength than its bufferless analog. It can be attributed to a higher electric field and well-ordered structure formed by applying the $\mathrm{H}_{2}$-diluted $p$ - $a$-SiC: $\mathrm{H}$ buffer layer at the $p / i$ interface. We conclude that the lightly doped $\mathrm{H}_{2}$-diluted $p$ - $a$-SiC: $\mathrm{H}$ buffer layer successfully reduces the recombination at the heterojunction interface by blocking the diffusion of boron into an $i-p c$-Si:H multilayer and relaxing the strain. ${ }^{11}$ Compared to $a$-Si:H cells, ${ }^{1,5}$ the bufferless multilayer cell shows the smaller variation at $400 \mathrm{~nm}$. It can be ascribed to the aforementioned weak natural hydrogen treatment effect during its $p / i$ interface formation.

$J_{D^{-}} V$ characteristics of $p c-\mathrm{Si}: \mathrm{H}$ multilayer cells are investigated to inspect the contribution of the $p / i$ interface on

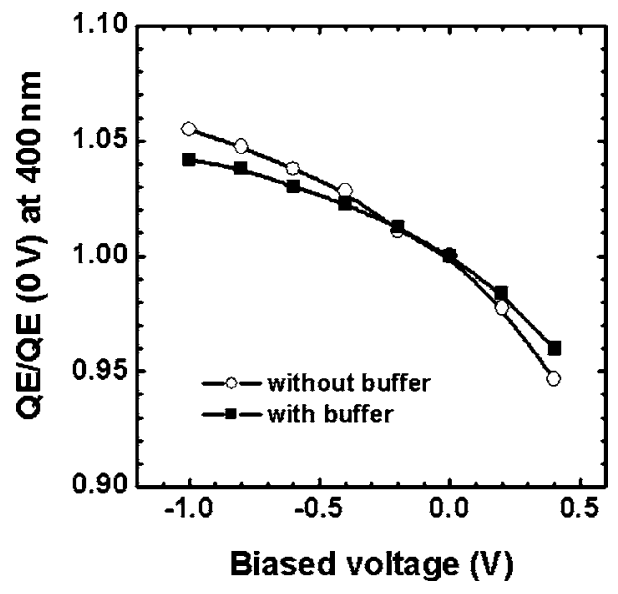

FIG. 3. Ratios of QE ( $V)$ to QE $(0 \mathrm{~V})$ at the short wavelength of $400 \mathrm{~nm}$. These values are evaluated from an initial $\mathrm{QE}$ of the optimized $p c-\mathrm{Si}: \mathrm{H}$ multilayer solar cell. 


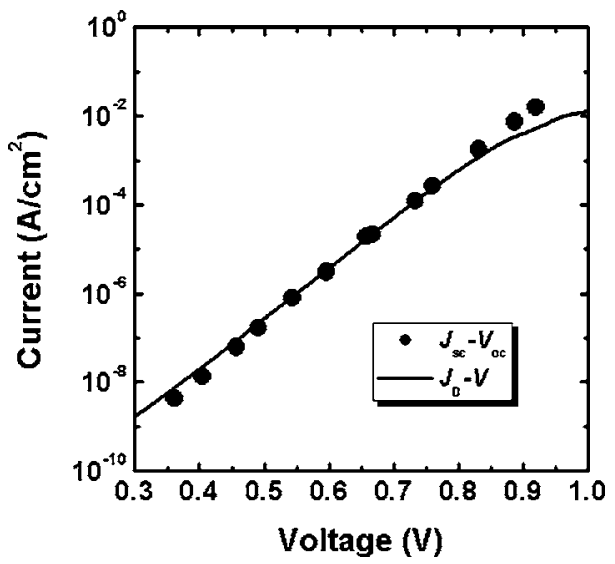

FIG. 4. Initial $J_{D^{-}} V$ characteristics of the optimized $p c-\mathrm{Si}: \mathrm{H}$ multilayer solar cell superimposed on its $J_{\mathrm{sc}}-V_{\mathrm{oc}}$ characteristics.

$V_{\text {oc }}$. The $J_{D}$ of multilayer cells can be expressed as

$$
J_{D}=J_{0}[\exp (q V / n k T)-1],
$$

where $J_{0}$ is the reverse saturation current density, $n$ is the diode quality factor, $q$ is the electric charge, $k$ is Boltzmann's constant, and $T$ is the absolute temperature. The effect of the $p / i$ interface to $V_{\text {oc }}$ can be identified from its dependence on the light illumination intensity. Applying a simplified model in which series and shunt resistance effects are negligible and the photocurrent density has no voltage dependence, we obtain the following equation by substituting $J_{\mathrm{sc}}$ and $V_{\mathrm{oc}}$ for $J_{D}$ and $V$ in Eq. (1), respectively:

$$
J_{\mathrm{sc}}=J_{0}\left[\exp \left(q V_{\mathrm{oc}} / n k T\right)-1\right] .
$$

Initial $J_{D^{-}} V$ and $J_{\mathrm{sc}}-V_{\mathrm{oc}}$ characteristics of the optimized $p c-\mathrm{Si}: \mathrm{H}$ multilayer cell are shown in Fig. 4. Due to the reversible recovery of the multilayer cell by the thermal annealing, ${ }^{6,8}$ its initial characteristics are the same as those in the annealed state. For $V<0.74 \mathrm{~V}, J_{D}$ shows an exponential dependence on $V$. In this regime, the carrier transport with $n=1.53$ can be ascribed to the injection of electrons and holes from $n-\mu c-\mathrm{Si}: \mathrm{H}$ layer and $p-a-\mathrm{SiC}: \mathrm{H}$ layers, respectively, which is followed by their diffusion and ultimate recombination. ${ }^{12}$ For $V \geqslant 0.74 \mathrm{~V}, J_{D}$ limited by a series resistance $^{13}$ and by a transition from diffusive to drift transport. ${ }^{14}$ We should note that $J_{D^{-}} V$ characteristics agree well with bulk recombination dominant $J_{\mathrm{sc}}-V_{\mathrm{oc}}$ characteristics with $n=1.45$ except for $V_{\text {oc }} \geqslant 0.8 \mathrm{~V}$. The wide overlap means that our multilayer cell is free from the recombination at the $p / i$ interface ${ }^{15}$ by the natural hydrogen treatment effect during the formation of the double $p-a-\mathrm{SiC}: \mathrm{H}$ layer structure.

Because of the highly conductive $\mathrm{H}_{2}$-diluted $p-a-\mathrm{SiC}: \mathrm{H}$ buffer layer, we improve the built-in potential $\left(\Delta V_{\mathrm{bi}}\right)$ at the $p / i$ interface, which can be expressed as ${ }^{5}$

$$
\Delta V_{\mathrm{bi}}=\Delta \varphi_{b}+\Delta E_{\mathrm{va}} \text {. }
$$

We achieved optical bandgap values of $p-a-\mathrm{SiC}: \mathrm{H}$ window $(\sim 2.0 \mathrm{eV})$ and buffer $(\sim 1.8 \mathrm{eV})$ layers via spectroscopic ellipsometry measurements. ${ }^{1,5}$ The optical bandgap of $i-p c-\mathrm{Si}: \mathrm{H}$ is slightly wider than undiluted $a-\mathrm{Si}: \mathrm{H}(\sim 1.7 \mathrm{eV})$, because of the quantum confinement by the isolated $n c-\mathrm{Si}: \mathrm{H}$ grains. ${ }^{7,8}$ It is considered that a high conductivity of the buffer improves the built-in potential of the $p c-\mathrm{Si}: \mathrm{H}$ multilayer solar cell: (i) by lowering a barrier potential $\left(\Delta \varphi_{b}\right)$ at the $\mathrm{SnO}_{2}:$ F/undiluted $p-a-\mathrm{SiC}: \mathrm{H}$ window interface due to the increase in the dark conductivity of the window layer, (ii) by the band lift arising from the Fermi level location of the buffer closer to the valence band edge of the $i-p c-\mathrm{Si}: \mathrm{H}$ absorber $\left(\Delta E_{\mathrm{va}}\right)$ due to the highly conductive $\mathrm{H}_{2}$-diluted $p$ - $a$-SiC: $\mathrm{H}$ buffer layer. Due to the improvement of $V_{\mathrm{bi}}$, the cell with the buffer shows the higher $V_{\mathrm{oc}}$ than its bufferless analog. This improvement of $V_{\mathrm{bi}}$ is also beneficial to prevent the electron backdiffusion. As mentioned earlier, the multilayer has the repeated layered structure consisting of $S_{L}$ 's and $S_{H}$ 's. In addition, all interfaces are graded by hydrogen. Isolated spherical $n c$-Si grains embedded in a well-ordered $a-\mathrm{Si}: \mathrm{H}$ matrix of $S_{H}{ }^{\prime}{ }^{8}{ }^{8}$ An $a-\mathrm{Si}: \mathrm{H}$ grain boundary layer with a high hydrogen concentration wraps each $n c$-Si grain. This grain boundary layer is the most defective layer in the multilayer. $S_{L}$ 's that hinder the columnar growth of $\mu c-\mathrm{Si}: \mathrm{H}$ have a less-ordered $a-\mathrm{Si}: \mathrm{H}$ matrix than that of $S_{H}$ 's.

The optimized $p c-\mathrm{Si}: \mathrm{H}$ multilayer solar cell exhibits a stabilized efficiency of $9.0 \% \quad\left(V_{\mathrm{oc}}=0.919 \mathrm{~V}, \quad J_{\mathrm{sc}}\right.$ $=15.0 \mathrm{~mA} / \mathrm{cm}^{2}, \mathrm{FF}=0.652$, and a degradation ratio [efficiency $(t>12 \mathrm{~h}) /$ efficiency $(t=0)]=13.4 \%)$ after $12 \mathrm{~h} 1$ sun $\left(100 \mathrm{~mW} / \mathrm{cm}^{2}, \mathrm{AM} 1.5\right)$ light irradiation at $50{ }^{\circ} \mathrm{C} .{ }^{7,8}$ Isolated $n c$-Si grains embedded in regularly arranged $S_{H}$ 's suppress the photocreation of dangling bonds. ${ }^{8,16}$ Due to virtually invariant $V_{\text {oc }}$, the $p c-\mathrm{Si}: \mathrm{H}$ multilayer solar cell has a low degradation behavior. Thus, the $\mathrm{H}_{2}$-diluted $p-a-\mathrm{SiC}: \mathrm{H}$ buffer layer contributes to the improvement of the stabilized efficiency by enhancing initial $V_{\text {oc }}$.

We are currently trying to achieve a higher conversion efficiency via a highly stable and textured intentionally hydrogen-doped $\mathrm{ZnO} \quad(\mathrm{ZnO}: \mathrm{H})^{17}$ or $\mathrm{ZnO}: \mathrm{H} / \mathrm{Ag}$ backreflector.

${ }^{1}$ S. Y. Myong, S. S. Kim, and K. S. Lim, J. Appl. Phys. 95, 1525 (2004). ${ }^{2}$ S. Y. Myong, H. K. Lee, E. Yoon, and K. S. Lim, J. Non-Cryst. Solids 298, 131 (2002); H. K. Lee, S. Y. Myong, K. S. Lim, and E. Yoon, ibid. 316, 297 (2003); S. Y. Myong, O. Shevaleevskiy, S. Miyajima, M. Konagai, and K. S. Lim, ibid. 351, 89 (2005).

${ }^{3}$ S. Y. Myong, T. H. Kim, K. H. Kim, B. T. Ahn, S. Miyajima, M. Konagai, and K. S. Lim, Sol. Energy Mater. Sol. Cells 81, 485 (2004).

${ }^{4}$ S. Y. Myong, O. Shevaleevskiy, S. Miyajima, M. Konagai, and K. S. Kim, J. Appl. Phys. 98, 054311 (2005).

${ }^{5}$ S. Y. Myong and K. S. Lim, Appl. Phys. Lett. 86, 033506 (2005).

${ }^{6}$ K. H. Jun, J. D. Ouwens, R. E. I. Schropp, J. Y. Lee, J. H. Choi, H. S. Lee, and K. S. Lim, J. Appl. Phys. 88, 4881 (2000).

${ }^{7}$ S. Y. Myong, S. W. Kwon, M. Konagai, and K. S. Lim, Sol. Energy Mater. Sol. Cells 85, 133 (2005).

${ }^{8}$ K. S. Lim, J. H. Kwak, S. W. Kwon, and S. Y. Myong, Mater. Res. Soc. Symp. Proc. 862, A.11.2 (2005).

${ }^{9}$ S. Y. Myong, S. S. Kim, and K. S. Lim, Thin Solid Films 455-456, 482 (2004).

${ }^{10}$ S. Y. Myong, S. S. Kim, and K. S. Lim, Appl. Phys. Lett. 84, 5416 (2004).

${ }^{11}$ R. R. Arya, A. Catalano, and R. S. Oswald, Appl. Phys. Lett. 49, 1089 (1986).

${ }^{12}$ J. Deng, J. M. Pearce, R. J. Koval, V. Vlahos, R. W. Collins, and C. R. Wronski, Appl. Phys. Lett. 82, 3023 (2003).

${ }^{13}$ H. Sakai, T. Yoshida, S. Fujikake, T. Hama, and Y. Ichikawa, J. Appl. Phys. 67, 3494 (1990).

${ }^{14}$ K. Lips, Mater. Res. Soc. Symp. Proc. 377, 455 (1995).

${ }^{15}$ J. M. Pearce, R. J. Koval, A. S. Ferlauto, R. W. Collins, C. R. Wronski, J. Yang, and S. Guha, Appl. Phys. Lett. 77, 3093 (2000).

${ }^{16}$ T. Kamei, P. Stradins, and A. Matsuda, Appl. Phys. Lett. 74, 1707 (1999).

${ }^{17}$ S. Y. Myong and K. S. Lim, Appl. Phys. Lett. 82, 3026 (2003). 